\title{
DEBIUTY
}

ANETA GĄSIŃSKA

Forum Pedagogiczne

$2017 / 1$

Wpłynęło: 10.02.2017

Zatwierdzono do druku: 29.03.2017

DOI: $10.21697 / \mathrm{fp} .2017 .1 .19$

\section{ODDZIAŁYWANIA KURATORA SĄDOWEGO WOBEC NIELETNICH NIEDOSTOSOWANYCH SPOLECZNIE}

\begin{abstract}
Streszczenie: Niedostosowanie społeczne to jedna z wyjątkowo niebezpiecznych form patologii społecznej, na którą najbardziej podatne są dzieci i młodzież, u których w procesie socjalizacji wystąpiły pewne zakłócenia. Nieprawidłowości w uspołecznianiu mogą być spowodowane różnymi czynnikami, do których zalicza się m.in.: osobowość jednostki, negatywne grupy odniesienia, wadliwie funkcjonującą rodzinę czy też niekorzystny wpływ mass mediów. Nieletni niedostosowani społecznie bardzo często kierowani są do poradni psychologiczno-pedagogicznych oraz świetlic socjoterapeutycznych, w celu wyeliminowania zachowań niekorzystnych, a w przypadku, gdy oddziaływania powyższych placówek nie przyniosą efektów, sądy rodzinne najczęściej przyznają nadzór kuratora. Niniejszy artykuł ma charakter teoretyczno-empiryczny, a przeprowadzone przez autorkę badania miały na celu poznanie metod pracy kuratora sądowego w stosunku do nieletnich.
\end{abstract}

Słowa kluczowe: kurator, nieletni, niedostosowanie społeczne, socjalizacja, resocjalizacja.

\section{Wprowadzenie}

Socjalizacja to proces składający się z interakcji zachodzących między człowiekiem a tym, co na niego wpływa. Umożliwia on osiągnięcie stanu dorosłości, czyli gotowości psychicznej do podejmowania decyzji zgodnych z zasadami i sposobem życia panującym w danym społeczeństwie (Pielkowa 2004). Poruszając temat socjalizacji, należy pamiętać, iż jest to proces trwający przez całe życie, przechodzący różnorodne stadia i przyjmujący różne formy, w zależności od stopnia rozwoju człowieka (Goodman 1997).

Adolescencja (okres szacowany między 10 a 20 rokiem życia) (Obuchowska 2003), jako jeden z dłuższych okresów w życiu człowieka, ma istotne znaczenie, ponieważ to właśnie w tym czasie w jednostce zachodzi najwięcej zmian, zarówno fizycznych, jak i psychicznych. Jest to moment usilnego poszukiwania własnej tożsamości oraz ostatecznego jej krystalizowania się. W tym okresie, w myśl teorii Erica Eriksona, pojawiają się dwa główne kryzysy, pierwszy to kryzys między tożsamością 
a pomieszaniem ról, którego rozwiązanie ma polegać na odkryciu przez młodego człowieka swojej prawdziwej tożsamości, natomiast drugi to kryzys między intymnością a izolacją, który ma na celu rozwinięcie zdolności do wytwarzania stałych i głębokich więzi emocjonalnych, moralnych i seksualnych. Aby móc wytworzyć ten rodzaj więzi, jednostka musi dojrzeć do częściowego zrezygnowania ze swojej prywatności i niezależności, następnie do rezygnacji z niektórych swoich osobistych preferencji, aby na końcu przyjąć pewne zobowiązania (Gerrig, Zimbardo 2011).

Socjalizacja adolescentów ma specyficzny charakter, ponieważ ten rodzaj grupy charakteryzuje się nad wyraz wzmożoną wrażliwością, napięciem wewnętrznym oraz zachwianą równowagą psychiczną. Emocje oraz poglądy młodzieży cechują się intensywnością, zmiennością, burzliwością, dynamicznością oraz nietrwałością, dlatego też bardzo częste są konflikty na linii dziecko-rodzic. Niezwykle łatwo jest wyprowadzić nastolatka $\mathrm{z}$ równowagi, ponieważ adolescencja to okres, w którym jednostka dopiero zaczyna budować obraz siebie, w związku z czym wszystko, co dzieje się w otaczającej rzeczywistości, odnosi do swojej osoby. Ze względu na powyższe, okres ten jest trudnym etapem w życiu człowieka, ponieważ młodzież nie do końca jest wówczas rozumiana nie tylko przez społeczeństwo i najbliższych, lecz także przez samych siebie, a przez to jest najbardziej podatna na negatywne oddziaływania zewnętrzne (Kędzior 2008).

Proces socjalizacji obejmuje zarówno indywidualne jednostki, jak i całe grupy. Czynników mających wpływ na jej prawidłowy lub też nieprawidłowy przebieg jest niezliczona ilość, jednakże do tych najważniejszych zalicza się: 1) rodzinę, która jest pierwszą grupą do której przynależy młody człowiek już od momentu narodzin; 2) szkołę, która w sposób bezpośredni oddziałuje na dziecko poprzez przekazywanie mu wiedzy, umiejętności oraz informacji; 3) grupy rówieśnicze, do których jednostka nie przynależy „z automatu”, a na swoją pozycję musi zapracować i zasłużyć; 4) osobowość jednostki, czyli sposób, w jaki młody człowiek postrzega siebie samego, innych oraz siebie w relacjach z innymi oraz 5) mass media (Goodman 1997).

\section{Kurator wobec nieletnich niedostosowanych społecznie}

Jednym z podmiotów pracy kuratora jest dziecko niedostosowane społecznie, czyli takie, u którego w efekcie zaburzeń wewnętrznych lub niekorzystnych oddziaływań środowiskowych pojawiły się utrwalone (powtarzające się) zaburzenia w zachowaniu. Są to osoby nieletnie wymagające opieki socjalnej oraz wzmożonych oddziaływań opiekuńczo-wychowawczych, terapeutycznych i resocjalizacyjnych (Pytka 2005).

Niedostosowanie społeczne jest jednym z głównych skutków wadliwej socjalizacji. Pojęcie to rozumiane jest jako sytuacja, w której znalazła się młoda osoba nieprzestrzegająca norm, zasad, postaw i ról oczekiwanych przez społeczeństwo oraz jako niezdolność jednostki do dostosowania własnego działania do pozycji, 
roli i statutu, jaki zajmuje w grupach społecznych (Szewczuk 1998). Podstawowymi objawami tak rozumianego niedostosowania społecznego są: notoryczne wagary, ucieczki z domu, kradzieże, wandalizm, używanie alkoholu, narkomania, demoralizacja seksualna, zachowania agresywne i inne. Wiąże się to $\mathrm{z}$ odrzuceniem powszechnie przyjętych norm moralnych, zasad, praw i wartości, co prowadzi do łamania obowiązującego prawa oraz do rozwiązłości obyczajowej (Drabik 2006).

Najdotkliwszym skutkiem niedostosowania społecznego nieletnich jest przestępczość, która kształtuje się w chwili, gdy jednostka w procesie socjalizacyjnym nie została wyposażona w mechanizmy antykryminogenne (kręgosłup moralny). Istnieje duży związek między przestępczością nieletnich a skutkami wadliwej socjalizacji. Nieprzedstawienie jednostce znaczenia respektowania zasad przyjętych za podstawowe w życiu społeczeństwa ułatwia, a wręcz zachęca do ich lekceważenia oraz kwestionowania, co w ostateczności prowadzi do ich pogwałcenia (Derlatka 2013).

W związku z powyższym, w myśl Ustawy z dnia 27 lipca 2001 roku kuratorzy sądowi realizują zadania o charakterze: 1) wychowawczo-resocjalizacyjnym, które mają na celu uzyskanie kluczowych zmian w osobowości wychowanka (Jedynak 2006); 2) diagnostycznym, w których podstawę stanowią wywiady środowiskowe zlecane kuratorom przez sąd, zanim zostanie wydane orzeczenie w konkretnej sprawie (Jadach 2011); 3) profilaktycznym, które odnoszą się do terenowej pracy kuratora i opierają się na bezpośrednich kontaktach z podopiecznym w jego naturalnym, często patologicznym środowisku (Szykut 2006); 4) kontrolnym, które mają na celu dopilnowanie wywiązywania się z obowiązków oraz poleceń nałożonych na nieletniego przez sąd, jak również monitorowanie zachowań wykazujących objawy demoralizacji i niedostosowania (Jadach 2011). Z kolei podstawowym zadaniem realizowanym przez kuratorów jest sprawowanie nadzoru nad małoletnimi zdemoralizowanymi lub dopuszczającymi się czynów karalnych, a w sprawach rodzinnych, nadzoru nad sposobem sprawowania władzy rodzicielskiej przez rodziców/opiekunów, którym ta władza została przez sąd ograniczona (Jadach 2011).

Za główny cel oddziaływań kuratorskich uważa się pomoc podopiecznemu w prawidłowym funkcjonowaniu w życiu społecznym. Ze względu na różnorodność osób objętych nadzorem, jak i ich zindywidualizowane problemy, kurator winien personalnie dobierać metody pracy, uwzględniając przy tym warunki środowiskowe nieletniego, jego cechy osobowości, ogólne przesłanki psychofizyczne, stopień demoralizacji oraz wszelkie jego zdolności i mocne strony (Wójcik, Buczkowski, Kulma 2010). W związku z tym wśród metod pracy stosowanych przez kuratorów sądowych wyróżnia się: 1) metodę indywidualnych przypadków, tzw. casework - wykorzystuje ona procedurę psychotechniczną w kontaktach kuratorwychowanek. Ma to olbrzymie znaczenie, szczególnie w odniesieniu do nieletnich, u których wytworzenie się więzi opartej na wzajemnym zaufaniu warunkuje cały proces efektywności oddziaływań kuratorskich. W ramach tej metody często wykorzystuje się mediację, kontrakt oraz negocjację.; 2) metodę pracy grupowej, 
tzw. groupwork - stosowaną głównie w ośrodkach kuratorskich; oraz 3) metodę pracy ze środowiskiem podopiecznych, tzw. network - polegającą na daleko idącej integracji oraz współpracy, możliwie z jak największą liczbą osób, jak również instytucji będących ośrodkami wsparcia nieletniego w kryzysie (Zinkiewicz 2003).

Na efektywność oddziaływań kuratora ma wpływ nie tylko odpowiedni dobór metod pracy, ale również sama osoba kuratora, którego sposób bycia może być czynnikiem pobudzającym i wyzwalającym reakcje pozytywne, albo czynnikiem hamującym naturalną postawę nieletniego (Makowski 1994). Kurator, poprzez funkcje, jakie winien pełnić, wciela się w specyficzne role społeczne, które wymagają określonych predyspozycji osobowościowych. Badacze zajmujący się tym problemem do najważniejszych cech osobowościowych kuratorów zaliczyli: sumienność, stanowczość, umiejętność nawiązywania kontaktów, zaradność, obiektywizm, wytrwałość, cechy przywódcze, dociekliwość, prawdomówność, pracowitość i uczciwość (Opora 2006).

Praca kuratora ma ogromne znaczenie w pracy z nieletnimi i w znaczący sposób rzutuje na ich życie. Aby oddziaływania były efektywne, ważny jest nie tylko odpowiedni dobór metod i technik, ale także osobowość kuratora, jego charyzma, podmiotowe podejście do nieletniego, skupienie się na osobie podopiecznego, a nie na czynie, jaki on popełnił. Nadzór kuratora sądowego jest najczęściej stosowanym środkiem wychowawczym w stosunku do młodzieży niedostosowanej społecznie. Należy jednak pamiętać, iż kurator w swojej pracy doznaje tak sukcesów, jak i porażek; na owoce pracy trzeba czekać niekiedy bardzo długo i nie zawsze mogą być one takie, jakie zostały uprzednio zaplanowane.

\section{Cel, problem i metoda}

W poniższym rozdziale zostały przedstawione wyniki badań własnych. Przedmiotem badań były oddziaływania kuratora sądowego wobec nieletnich niedostosowanych społecznie, głównym ich celem natomiast było poznanie metod pracy kuratora sądowego. Podejmując się przeprowadzenia badań empirycznych, zmierzano do ustalenia: 1) z jakich powodów został orzeczony nadzór nad młodzieżą?; 2) jaka była sytuacja rodzinna podopiecznych kuratora?; 3) jaka była sytuacja szkolna nieletnich przebywających pod nadzorem ankietowanej grupy?; 4) jakie były metody pracy badanej grupy wobec podopiecznych?; 5) co zmieniło się w sytuacji osób nadzorowanych?

Mając powyższe na uwadze, kluczowa hipoteza zakładała, iż głównymi oddziaływaniami kuratora sądowego wobec nieletnich niedostosowanych społecznie są przede wszystkim oddziaływania opiekuńczo-wychowawcze oraz profilaktyczno-resocjalizujące. Co do postawionych wyżej pytań natomiast hipotezy przedstawiały się w sposób następujący: 1) bezpośrednią przyczyną orzekania nadzoru jest popełnienie czynu karalnego przez nieletniego, a dodatkowo szeroki wachlarz przejawów niedostosowania społecznego; 2) sytuacja rodzinna nieletnich charakteryzuje się 
dwoma skrajnościami - pierwszą grupę stanowią rodziny, w których nie występują żadne konflikty mogące mieć negatywny wpływ na rozwój i prawidłowe funkcjonowanie nieletniego, drugą grupę natomiast stanowią rodziny, w których konflikty były bardzo częste; 3) sytuacja szkolna nieletnich objętych nadzorem kuratora jest zła bądź krytyczna, charakteryzuje się bardzo niesystematycznym lub całkowitym brakiem realizacji obowiązku szkolnego; 4) najczęściej stosowaną metodą w pracy kuratorów jest metoda indywidualnych przypadków, tzw. casework; (5) sytuacja osób objętych nadzorem kuratora sądowego uległa poprawie.

Badania zostały przeprowadzone na grupie warszawskich kuratorów zawodowych i społecznych. Przebadanych zostało 86 kuratorów (66 kobiet, co stanowi 77 proc. oraz 20 mężczyzn, co stanowi 23 proc. badanej grupy), z czego 14 osób pełni funkcję kuratora zawodowego (13 kobiet, jeden mężczyzna), 72 respondentów natomiast to kuratorzy społeczni (53 kobiety, 19 mężczyzn). Kuratorzy zawodowi mieścili się w grupie wiekowej 30-50 lat, społeczni natomiast - 24-64 lata. Odnosząc się do wykształcenia ankietowanych kuratorów, 72 osoby (co stanowi 84 proc. badanej grupy), zadeklarowały, iż posiadają wykształcenie wyższe, natomiast 18 osób (kuratorów społecznych), iż ich wykształcenie jest na poziomie średnim. Ankietowani charakteryzowali się różnym doświadczeniem zawodowym/stażem pracy, które w przypadku kuratorów zawodowych wynosiło od 3 do 20 lat, natomiast u kuratorów społecznych od roku do 25 lat. Do przeprowadzenia badania została wykorzystana metoda sondażu diagnostycznego. Wykorzystano w tym celu technikę ankiety pisemnej, przy czym narzędziem badawczym był kwestionariusz ankiety (Łobocki 2006).

\section{Powody orzekania nadzoru a sytuacja szkolna i rodzinna}

Kuratorzy w swojej pracy spotykają się z wieloma powodami orzekania nadzoru, a co za tym idzie, $\mathrm{z}$ szerokim wachlarzem form niedostosowania społecznego nieletnich. Przeprowadzone badania ukazały, iż w opinii 83 proc. ankietowanych kuratorów najczęstszym powodem orzekania nadzoru były ustawiczne wagary, dodatkowo 64 proc. respondentów wskazało rozbój, 53 proc. kradzieże, a dopiero w dalszej kolejności badani zaznaczyli również pobicia (37 proc.), chuligaństwo (30 proc.), włamania (23 proc.) oraz jako inne, posiadanie narkotyków (12 proc.)².

Ankietowani kuratorzy wśród przyczyn, przez które nieletni popadli w konflikt z prawem, niemal na równym miejscu zaznaczyli chęć zaimponowania (83 proc.), niewłaściwą grupę rówieśniczą (82 proc.) oraz trudności w szkole (77 proc.), a dopiero dalej uplasowały się nałogi rodziców (51 proc.), jak również zaburzenia psychiczne (23 proc.). Jak łatwo zauważyć, trzy pierwsze miejsca są ze sobą ściśle powiązane. Okres adolescencji jest czasem, kiedy jednostka poznaje

${ }^{1}$ (przyp. autora). Wyniki badań nie sumują się do 100 proc., gdyż respondenci mieli do wyboru więcej niż jedną odpowiedź 
siebie, szuka swojej tożsamości, potrzebuje przynależności do grupy wyznającej te same lub podobne wartości i normy. Jest to okres budowania swojej oceny oraz wartości. Chęć doświadczenia akceptacji ze strony rówieśników, dowartościowania siebie pcha młode osoby do popełniania złych czynów. Są oni gotowi do zrobienia niemal wszystkiego, byleby tylko być szanowanym i akceptowanym. Kradzieże, pobicia, używanie alkoholu czy narkotyków są to najczęstsze formy, a raczej próby zaimponowania grupie.

Często przyczyn niedostosowania społecznego nieletnich należy szukać w pierwszym, podstawowym środowisku ich życia. W przeprowadzonych badaniach 43 proc. kuratorów wskazało, że ich podopieczni pochodzili z rodzin pełnych, nieco mniej natomiast, gdyż 39 proc., że z rodzin rozbitych. Aż 70 proc. ankietowanych wskazało, że w domu nieletnich można zaobserwować zachowania patologiczne, w opinii 33 proc. badanych patologiczne są zachowania ojca; w 16 proc. - obojga rodziców; w 13 proc. - niekorzystne zachowania całej rodziny; siedem proc. - zachowania matki, a u jednego proc. - zachowania rodzeństwa. Pocieszający jest fakt, iż prawie jedna trzecia ankietowanych kuratorów (30 proc.) zadeklarowała, iż w rodzinie podopiecznego nie występują żadne zachowania patologiczne. Badania ukazały, że zdaniem niemal jednej trzeciej ankietowanych nieletni będący pod nadzorem kuratora wywodzą się z rodzin funkcjonujących prawidłowo, nieodznaczających się żadnymi formami niedostosowania społecznego czy zachowań patologicznych. Zatem, należy podkreślić, iż nie trzeba stygmatyzować i myśleć stereotypowo, iż młodzież przestępcza wywodzi się tylko i wyłącznie z rodzin patologicznych - gdyż, jak widać na podstawie wyników badań, jest to stwierdzenie krzywdzące i nieprawdziwe.

Oceniając sytuację materialno-socjalną rodziny podopiecznego, ankietowani kuratorzy deklarują w 43 proc., iż jest ona dobra lub bardzo dobra (19 proc.). Niestety jednak, aż 31 proc. respondentów stwierdziło, iż sytuacja jest zła lub bardzo zła (siedem proc.). Dodatkowo aż 68 proc. ankietowanych kuratorów uważa, że w domu podopiecznego panuje niekorzystna atmosfera, z czego: 36 proc. respondentów stwierdziło, iż jest to atmosfera napięta; 24 proc., że atmosfera konfliktowa i po cztery proc., że atmosfera wroga oraz stresowa. Pocieszający jest fakt, że 32 proc. badanych zadeklarowało, $i \dot{z}$ w rodzinie nieletniego panuje atmosfera korzystna (17 proc. - życzliwa; 14 proc. - ciepła; jeden proc. - pogodna).

Nieletni niedostosowani społecznie manifestują swoje nieprzystosowanie nie tylko w domu czy grupie rówieśniczej, lecz także, można byłoby nawet powiedzieć, że przede wszystkim, w szkole. Charakteryzuje się to nie tylko drugorocznością czy ustawicznym wagarowaniem, ale również okazywaniem braku szacunku w stosunku do nauczycieli, niszczeniem mienia szkolnego czy wulgarnym i agresywnym zachowaniem w stosunku do pracowników szkoły. Odnosząc się do frekwencji szkolnej, badani kuratorzy wykazali, że 34 proc. $z$ ich podopiecznych posiada obecność szkolną na poziomie 50-6o proc., co piąty natomiast (20 proc.) - na poziomie 40-50 proc., czyli minimalnego pułapu, aby zostać zaklasyfikowanym do następnej 
klasy i mieć możliwość zdobycia promocji. Niepokojący jest fakt, iż w opinii 26 proc. badanych co czwarty uczeń nie osiąga frekwencji wyższej niż cztery proc., co jest równoznaczne $z$ drugorocznością. Zaledwie 19 proc. respondentów stwierdziło, iż ich podopieczni osiągają obecność wyższą niż 60 proc. (6o-70 proc. - 16 proc.; 70-80 proc. - trzy proc.).

Kolejne bardzo niepokojące wyniki badań dotyczą oceny z zachowania nieletnich, które ukazały, że w opinii ankietowanych kuratorów aż 34 proc. nadzorowanych otrzymało ocenę naganną. Nieco powyżej połowy (51 proc.) - ocenę nieodpowiednią, natomiast zachowanie poprawne wśród swoich podopiecznych wskazało zaledwie dziewięć proc. kuratorów, a dobre sześć proc. Ankietowani kuratorzy nie zadeklarowali, aby któryś z ich podopiecznych osiągnął zachowanie bardzo dobre lub wzorowe.

\section{Metody pracy i zmiana w sytuacji osób nadzorowanych}

Odpowiedni dobór metod i technik oraz kompleksowe podejście do podopiecznego mogą być determinantem efektywnych oddziaływań. Z przeprowadzonych badań wynika, że najczęściej stosowaną techniką w pracy z nieletnim jest wywiad, dzięki któremu kurator może zebrać najwięcej informacji. A najczęstszą metodą jest metoda indywidualnych przypadków, którą zadeklarowali wszyscy ankietowani. Caswork wydaje się być metodą najbardziej skuteczną, umożliwiającą wytworzenie się między kuratorem a nieletnim więzi opartej na szacunku i zaufaniu. Ankietowani, jako metody wspierającej używają metody pracy grupowej (53 proc.), mediacji (27 proc.) oraz innych środków, np. metody wpływu osobistego (17 proc.).

Zdaniem badanych, do głównych zadań realizowanych przez kuratorów zaliczają się zadania o charakterze resocjalizacyjnym (94 proc.) oraz zadania wspomagające sąd, na trzecim miejscu znajdują się dopiero zadania o charakterze profilaktycznym, a na czwartym - organizacyjne. Kuratorzy niemalże wszyscy odpowiedzieli, że najważniejszym celem sprawowania nadzoru nad nieletnim jest próba zmiany jego postawy z aspołecznej na prospołeczną (49 proc.) oraz kontrola zachowań i obowiązków nałożonych na nieletniego przez sąd (45 proc.). Ciekawe i niezbyt dobrze rokujące jest to, że zaledwie sześć proc. respondentów uważa, że celem nadzoru powinno być wsparcie nieletniego.

Tak jak już wielokrotnie wcześniej było wspominane, wszelkie działania kuratora dążą do wprowadzenia pozytywnych zamian w życiu podopiecznego oraz jego rodziny, do zmiany jego postawy $z$ aspołecznej na prospołeczną. Zmianę środowiska życia nieletniego, jako determinant skutecznej resocjalizacji, uważa za ważną 74 proc. respondentów.

Odnosząc się do zmian, jakie zaszły w życiu nieletnich przebywających pod opieką kuratora, wyniki badań przedstawiają się w następujący sposób: aż 63 proc. ankietowanych uważa, że główną zmianą związaną z nałożeniem nadzoru kuratorskiego jest poprawa frekwencji szkolnej nieletniego. Ponadto, 55 proc. badanych 
deklaruje, iż dzięki dozorowi zwiększyła się zdawalność podopiecznych do następnej klasy, a co za tym idzie, w opinii 49 proc. respondentów w znaczącym stopniu poprawiły się oceny szkolne. Dodatkowo aż 35 proc. badanych twierdzi, że nadzorowani biorą aktywny udział w życiu szkolnym, natomiast 34 proc. przyznaje, że mimo sprawowanego dozoru sytuacja szkolna podopiecznych nie uległa żadnej większej zmianie.

Co ciekawe, 38 proc. ankietowanych kuratorów uważa, że dzięki sprawowanemu nadzorowi w znaczącym stopniu poprawił się stosunek nieletnich do nauczycieli, czego głównym efektem jest odnoszenie się do nich z szacunkiem i respektem. Jednakże aż 30 proc. jest zupełnie innego zdania i twierdzi, że stosunek nieletnich nie zmienił się ani odrobinę, przez co należy rozumieć, iż nie uległ on poprawie, ale również i to, że się nie pogorszył. Kolejne 30 proc. deklaruje, iż trudno jest im wypowiedzieć się w tej kwestii, natomiast dwa proc. nie jest w stanie stwierdzić, czy sytuacja uległa jakiejkolwiek zmianie. Należy pamiętać, że efekty pracy kuratora nie pojawiają się z dnia na dzień, lecz wprost przeciwnie, często trzeba na nie bardzo długo czekać.

Co do zmian w sytuacji rodzinnej, ponad 50 proc. ankietowanych kuratorów uważa, że dzięki sprawowanemu nadzorowi w dużym stopniu poprawiły się relacje nieletniego z rodziną (53 proc.), jak również poprawiła się sytuacja materialna rodziny, poprzez działania kuratora w Ośrodku Pomocy Społecznej oraz w innych instytucjach pomocowych. Ponadto 43 proc. respondentów deklaruje, iż uzależnieni od różnych substancji rodzice oraz rodzeństwo nieletniego podjęli leczenie odwykowe. Dodatkowo 33 proc. kuratorów wskazuje, że atmosfera rodzinna uległa poprawie i obecnie jest ciepła i życzliwa, a bezrobotni członkowie rodziny podjęli pracę zarobkową. Co więcej, w opinii 29 proc. ankietowanych w rodzinach zaniechano stosowania przemocy domowej. Natomiast zaledwie 13 proc. uważa, iż sytuacja rodzinna podopiecznych nie zmieniła się w ogóle, a dwa proc. nie potrafi powiedzieć, czy w domach podopiecznych zaszła jakakolwiek zmiana - może być to spowodowane stosunkowo krótkim czasem, jaki minął od objęcia nadzoru kuratorskiego nad podopiecznym.

\section{Podsumowanie}

Niedostosowanie społeczne stanowi jedną z form patologii społecznej, która jest wyjątkowo niebezpieczna. Nieprawidłowości w uspołecznianiu mogą być spowodowane różnymi czynnikami, dlatego też praca kuratora ma ogromne znaczenie i w znaczący sposób rzutuje na późniejsze życie podopiecznego. Nadzór kuratora sądowego jest najczęściej stosowanym środkiem wychowawczym w stosunku do młodzieży niedostosowanej społecznie. Poprzez systematyczny i bezpośredni kontakt kurator jest w stanie stworzyć pełną diagnozę potrzeb nieletniego, usunąć część czynników patogennych oraz nauczyć podopiecznego konstruktywnego radzenia sobie z agresją, jak również może wspierać go w sytuacjach trudnych. 
Podsumowując powody, dla których najczęściej został orzekany nadzór, ponad 75 proc. badanych kuratorów wskazało na wagary, rozbój oraz kradzieże. Rutynowo spotykanymi formami niedostosowania społecznego było używanie alkoholu oraz agresja. Należy tu również dodać, iż ankietowani w wysokim procencie wskazali także na używanie narkotyków. Często wiązało się to z niewłaściwą grupą, w której funkcjonował podopieczny, a co dalej za tym idzie, chęcią dopasowania się, zaimponowania - bycia akceptowanym. Młodzież mająca trudności w szkole, charakteryzująca się pewnymi zaburzeniami psychicznymi. Inną przyczyną było wywodzenie się z rodzin patologicznych lub "normalnych”, ale pozbawionych empatii, akceptacji, atmosfery ciepła czy życzliwości, czego podopieczni szukali w każdy możliwy sposób, w każdym możliwym miejscu, nawet jeżeli wiązało się to $\mathrm{z}$ wkroczeniem na ścieżkę przestępczą.

Badania potwierdziły, iż sytuacja rodzinna nieletnich charakteryzowała się dwoma skrajnościami. Pierwszą grupę stanowią rodziny funkcjonujące prawidłowo, drugą natomiast rodziny, u których zaobserwowano występowanie patologii, m.in. takich jak: alkoholizm obojga lub jednego z rodziców, przemoc domowa względem dorosłych lub dzieci, ubóstwo, bezrobocie, choroby psychiczne i inne. Bardzo krzywdzące jest zatem założenie, że nieletni przejawiający zachowania ryzykowne pochodzą tylko z rodzin rozbitych i dysfunkcyjnych.

Z kolei sytuacja szkolna osób przebywających pod nadzorem badanej grupy charakteryzowała się bardzo niesystematycznym lub całkowitym brakiem realizacji obowiązku szkolnego przez nieletnich, co zostało zweryfikowane w 46 proc., a więc aż tylu nieletnich nie uzyskiwało frekwencji wyższej niż 50 proc., czyli pewnego minimum umożliwiającego zaliczenie roku szkolnego. Nieco więcej niż połowa badanych kuratorów zadeklarowała, iż ich podopieczni otrzymali ocenę nieodpowiednią. Na ocenę składa się wiele czynników nie tylko dopuszczalne zachowanie, ale również frekwencja i średnia ocen. Nieletni systematycznie opuszczający zajęcia, ustawicznie wagarujący nie mają szans na uzyskanie oceny poprawnej czy też nieodpowiedniej z zachowania, przez co aż ponad jedna czwarta z nich charakteryzuje się drugorocznością.

Najczęściej stosowaną metodą w pracy kuratorów z nieletnimi jest tzw. casework, co potwierdzili wszyscy ankietowani. Metoda indywidualnych przypadków pozwala na dopasowanie form i technik pracy, które w odniesieniu do konkretnej jednostki powinny odnieść jak największe efekty, a zatem metoda ta umożliwia kuratorowi kompleksowe podejście do osoby wychowanka oraz zindywidualizowanie jego potrzeb. Odnosząc się do zadań, jakie wykonuje kurator, prawie 94 proc. ankietowanych wskazało, iż mają one głównie charakter resocjalizacyjny, mający na celu pozytywne zmiany w osobowości i zachowaniu podopiecznego, przemianę jego postawy $z$ aspołecznej na prospołeczną.

Odnośnie zmian, jakie zaszły w sytuacji nieletnich przebywających pod opieką kuratora, w pierwszej kolejności należy zauważyć te związane z życiem szkolnym, ponieważ to właśnie w tym wymiarze ankietowani wskazywali największą 
efektywność działań resocjalizacyjnych. Aż 63 proc. badanych kuratorów zadeklarowało, że frekwencja podopiecznych w szkole poprawiła się znacząco , co wiązało się z systematycznym uczęszczaniem na zajęcia, zwiększyła się zdawalność podopiecznych do następnej klasy, a także poprawiły się ich oceny. Odnosząc się do sytuacji rodzinnej, panujące stosunki uległy poprawie w 53 proc., dzięki czemu badana młodzież zrozumiała, jak ważne są relacje z rodzicami oraz rodzeństwem. Ponadto, niemalże połowa ankietowanych kuratorów zadeklarowała, iż uzależnieni od różnych substancji członkowie rodziny podjęli leczenie odwykowe, dzięki czemu atmosfera rodzinna uległa ociepleniu, w znaczącym stopniu zmniejszyły się zachowania agresywne, osoby stały się bardziej wyrozumiałe, a w ich wzajemnych relacjach nie brakuje wzajemniej pomocy.

\section{Bibliografia}

Buczkowski D., Kulma R., Wójcik D. (2010). Badanie ankietowe kuratorów zawodowych i społecznych pionu karnego i rodzinnego. W: Wójcik D. (red.). Kuratela sadowa. Sukcesy i porażki. Warszawa: SCHOLAR.

Derlatka M. (2013). Przestępczość jako skutek wadliwej socjalizacji w rodzinie. „Jurysta”, z. 2. Warszawa: In Plus.

Drabik L. (2006). Patologia. W: Drabik L., Kubiak-Sokół A., Sobol E., Wiśniakowska L. (red). Słownik języka polskiego. Warszawa: PWN.

Gerrig R. J., Zimbardo P. G. (2011). Psychologia i życie (wydanie nowe). Warszawa: PWN.

Goodman N. (1997). Wstęp do socjologii. Poznań: Zysk i S-ka.

Jadach K. (2011). Praca kuratora sądowego w sprawach rodzinnych, nieletnich i karnych. Poznań: Wydawnictwo UAM.

Jedynak T. (2006). Kuratorska Stużba Sądowa - przeciwdziałanie niedostosowaniu społecznemu w warunkach wolnościowych. W: Kościelak R. (red.). Problem niedostosowania społecznego - oddziaływania w warunkach wolnościowych $i$ w izolacji penitencjarnej. Słupsk: Wydawnictwo Pomorskiej Akademii Pedagogicznej.

Kędzior J. (2008). Młodzież jako specyficzna kategoria społeczna. W: Kurzępa J., Lisowska A., Pierzchalska A. (red.). Współczesna młodzież pomiędzy Eros a Thanatos. Wrocław: Agencja Wydawnicza „ARGI”.

Łobocki M. (2006). Wprowadzenie do metodologii badań pedagogicznych. Kraków: Impuls.

Makowski A. (1994). Niedostosowanie społeczne młodzieży i jej resocjalizacja. Warszawa: PWN.

Obuchowska I. (2001). Adolescencja. W: Harwas-Napierała B., Trempała J. (red.). Psychologia rozwoju człowieka. Charakterystyka okresów życia, t. 2. Warszawa: PWN.

Opora R. (2006). Rola sędziów i kuratorów w resocjalizacji nieletnich. Gdańsk: Wydawnictwo Uniwersytetu Gdańskiego. 
Pielkowa J. A. (2004). Zmiany w pełnieniu funkcji socjalizacyjnej w rodzinie. W: Tyszka Z. (red.). Współczesne rodziny polskie - ich stan i kierunek przemian. Poznań: Wydawnictwo Naukowe UAM.

Pytka L. (2005). Pedagogika resocjalizacyjna. Wybrane zagadnienia teoretyczne, diagnostyczne i metodyczne. Warszawa: Wydawnictwo APS.

Szewczuk W. (1998). Słownik psychologiczny. Warszawa: Wydawnictwo Wiedza Powszechna.

Sztumski J. (2005). Wstęp do metod i technik badań społecznych. Katowice: Wydawnictwo Naukowe Śląsk.

Szykut M. (2006). Funkcjonowanie kuratorskiej służby sądowej po 2002 roku - przełom czy stagnacja? W: Kościelak R. (red.). Problem niedostosowania społecznego oddziaływania $w$ warunkach wolnościowych $i$ w izolacji penitencjarnej. Słupsk: Wydawnictwo Pomorskiej Akademii Pedagogicznej.

Zinkiewicz B. (2003). Metody i formy pracy kuratorów sądowych. W: Różycka E. (red.). Encyklopedia pedagogiczna XXI wieku, t. II: G-Ł. Warszawa: ŻAK.

\title{
ACTIONS OF A PROBATION OFFICER TOWARD SOCIALLY MALADJUSTED MINORS
}

\begin{abstract}
Social maladjustment is one of the extremely dangerous forms of social pathology, the most vulnerable are children and young people, in whom in the process of socialization some disruption occurred. Irregularities in the process of socialization can be caused by various factors, including personality, negative reference groups, defective functioning in families or adverse effects of mass media. Socially maladjusted minors are at first directed to the psychological and pedagogical clinics or to community day centres. In case the actions of those socialization institutions do not work, then family courts impose probation. The thesis has a theoretical and empirical character. Its aim was to analyze the methods of work of probation officers with the socially maladjusted minors.
\end{abstract}

Keywords: probation officer, minor, socially maladjusted, socialization of adolescents, reclamation.

Aneta Gąsińska - magister pedagogiki, absolwentka Wydziału Nauk Pedagogicznych Uniwersytetu Kardynała Stefana Wyszyńskiego. Adres e-mailowy: aneta.gasinska@gmail. com. 